\title{
Analysis of Potential Reduce Methane Gas Emission by Methanotrophs Bacteria from Rice Field in Gowa
}

\author{
Maimuna Nonci ${ }^{1}$, Baharuddin ${ }^{2}$, Burhanuddin Rasyid ${ }^{3} \&$ Pirman $^{4}$ \\ ${ }^{1}$ Faculty of Graduate School of Agriculture Hasanuddin University, Makassar, Indonesia \\ ${ }^{2}$ Centre of Research Agriculture Biotecnology Hasanuddin University,Makassar, Indonesia \\ ${ }^{3}$ Departments of Soil, Faculty of Agriculture, Hasanuddin University, Makassar, Indonesia \\ ${ }^{4}$ Department of Polytechnic Ujung Pandang, Makassar, Indonesia \\ Correspondence: Baharuddin, Centre of Research Agriculture Biotecnology, Hasanuddin University, Makassar, \\ Indonesia. Tel: 6281-2410-5053. E-mail: baharunhas@yahoo.com
}

Received: January 20, 2016

Accepted: March 31, 2016

Online Published: May17, 2016

doi:10.5539/mas.v10n7p183

URL: http://dx.doi.org/10.5539/mas.v10n7p183

\begin{abstract}
The increase of temperature in atmosphere caused by increasing concentrations of methane in rice field which is affects to the metabolism of rice plants, it can reduce productivity of rice. Methanotrophs bacteria is one of the organisms that can reduce methane gas emissions, because the bacteria use methane as a source of energy. Based on the fact, need information about the potential reduce of methane gas by the bacteria. The aim of this study is to analyze the potential reduce of methanotrophs bacteria that have been isolated from rice fields in Gowa previously. The Analysis conducted through measuring concentration of methane gas by chromatography gas techniques. Observations of remaining gas concentration were conclude four times during 13-days incubation period. All isolates were able reduce the methane with varies potential. The highest reduction was shown from isolates GMP 2 with the reduction about 88\% and the lowest reduction was shown from GMV 3 with the reduction about $51.40 \%$.
\end{abstract}

Keywords: emission, methane, methanotrophs

\section{Introduction}

The increase of temperature in atmospheric has a direct impact on the metabolic processes of plants i.e., respiration rate, transpiration, photosynthesis, water consumption and nutrients. Besides the increase of temperature in micro climate around the plant will accelerate to loss soil moisture due evaporation process. Las (2007) said identical words that the increase of temperature tocause increase of transpiration, water consumption, accelerate ripening of fruit, seeds and to increase pests and diseases, therefore it will cut the productivity. Also Peng et al (2008) reported that the increase of temperature average about $10^{\circ} \mathrm{C}$ can reduce the productivity of grain about $10 \%$.

Methane (CH4) is a greenhouse gas (GHG) that concentrate on the atmosphere is increasing each year, causing a rise in global temperatures. It is also increases in GHG emissions caused by methane which is very significant. Anonymous (2010) reported that total emissions from agricultural sector about $75.420 \mathrm{Gg}$ in 2000 with a contribution of methane about $21,5 \%$ and then in 2005 reported total GHG emissions about $80.179 \mathrm{Gg}$ with a contribution of methane about $65 \%$. The data illustrate that increase of methane emissions on the atmosphere about $44 \%$ for 5 years.

Methane gas produced in the rice field by methanogenic bacteria in anaerobic conditions. But in aerobic conditions methane can be utilized by methanotrophs bacteria as a source of carbon. Conrad and Rothfus (1991) reported that the oxidation process of methane is done by metanotrophs bacteria in aerobic conditions on the surface layer of rice field. The fact is supported by Hutchens et al (2003) that methanotrophs bacteria are active to convert methane in to complex organic in aerobic conditions to maintain their community. Oxidation of methane by metanotrophs bacteria in rice fields could reach about $80 \%$, from all production of the methane by 
methanogenic bacteria (Conrad and Rothfus, 1991).

The previous research has isolated sample from rice fields in Gowa (Nonci, 2015). Several collections of isolates has a character that is similar to the morphology and physiology of methanotrophs bacteria i.e., GMV 1, GMV 3, GMV 9, GMR 1, GMR 8, and GMP 2, GMP 4. It was been analyzed to determine it is potential of reducing methane. The study is necessary in order to obtain isolates that can be used as a biological agent, as an effort to suppress the rate of increasing concentration of methane on the atmosphere. In addition, it is also necessary to minimize the negative impact of increasing air temperature, so that the rice production would not decreased.

\section{Methods and Material}

Materials used in this research were methanotrophs bacterial isolate from Gowa, which had been previously isolated by Nonci (2015) i.e., GMV 1, GMV 3, GMV 9, GMR 1, GMR 8, GMP 2 and GMP 4.

The medium used is Nitrate Mineral Salt (NMS) as a selective medium (Hanson, 1998). Medium containing: 1.0 g Mg SO $.7 \mathrm{H}_{2} \mathrm{O} ; 1.0 \mathrm{~g} \mathrm{KNO}_{3} ; 0.717 \mathrm{~g} \mathrm{Na}_{2} \mathrm{HPO}_{4} .12 \mathrm{H}_{2} \mathrm{O} ; 0.272 \mathrm{~g} \mathrm{KH}_{2} \mathrm{PO} 4 ; 0,2$ g CaCl $.6 \mathrm{H}_{2} \mathrm{O} ; 4.0 \mathrm{~g} \mathrm{NH} 4 \mathrm{Cl}$; $0.5 \mathrm{ml}$ Trace Element Solution with composition: $0.5 \mathrm{~g} \mathrm{Na}_{2}$ EDTA; $0.2 \mathrm{~g} \mathrm{FeSO}_{4} .7 \mathrm{H}_{2} \mathrm{O} ; 0.03 \mathrm{~g} \mathrm{H}_{3} \mathrm{BO}_{3} ; 0.02 \mathrm{~g}$ $\mathrm{CoCl}_{2} .6 \mathrm{H}_{2} \mathrm{O} ; 0.01 \mathrm{ZnSO}_{4} .7 \mathrm{H}_{2} \mathrm{O} ; 3.0 \mathrm{mg} \mathrm{Mn} \mathrm{Cl} 2.4 \mathrm{H}_{2} \mathrm{O} ; 3.0 \mathrm{mg} \mathrm{Na} \mathrm{MoO}_{4} ; 2.0 \mathrm{mg} \mathrm{NiCl} \mathrm{Na}_{2} .6 \mathrm{H}_{2} ; 1.0 \mathrm{mg}$ $\mathrm{CaCl}_{2} .2 \mathrm{H}_{2} \mathrm{O}$. As an addition to the material used, there are also methane, bacto $20 \mathrm{~g} / 1$, Alcohol $70 \%$, sprites, wrapping, sterile water. The tools used include: autoclave, electric scales, petri dish, micro pipet, spray, laminar cabinet, syring, a unit of Chromatography gas, and other materials for usual laboratory analysis.

\subsection{Purification of Methanotrophs Bacteria}

Isolates of methanotrophs bacteria were purified by gently streaking the colonies by quadrant streak method in to copper free NMS medium. The bacteria grown on NMS medium were incubated until the pure colonies of mehanotrophs were obtained. All of the pure colonies were then transferred in to NMS containing $10 \%$ methanol.

\subsection{Analysis for Potential Reduce of Methane Gas}

Isolates were tested for potential reduction of methane using chromatography gas Shimatdzu 8A equipped with Flame Ionization Detector (FID), Capillary Colum, Nitrogen and Helium gas carrier. Results of the analysis are interpreted by concentration.

Potential reduction test of methane is done by measuring the concentration of methane in the headspace using gas chromatography technique, which is a method modifed by Kumaraswarni et al (2001). 1 ml liquid culture isolates were inoculated in to $9 \mathrm{ml}$ NMS medium in a $20 \mathrm{ml}$ vial tube, the gas composition in the headspace tubes made approximately 50\% methane and 50\% air, then closed and plugged with rubber. As a control, there was an NMS medium in $10 \mathrm{ml}$ vial tube with a gas composition that are same with the headspace. Incubation was carried for 13 days on the shaker at room temperature $\left(27-30^{\circ} \mathrm{C}\right)$. Methane concentration measured every four days during the incubation period.

Percentage of potential reduction methane during the incubation period is calculated using formula:

$$
\text { Percentage of Reduction }=\frac{\text { Early of Concentration-Late of Concetration }}{\text { Early of Cocentration }} \times 100 \%
$$

\section{Results}

Observation for methane concentration of remaining against 7 isolates showed that all isolates were able to reduce methane with varies potential (Table 1). The highest reduction shown by GMP 2 isolate with concentration from $10 \mathrm{ppm}$ on the first day to $1.20 \mathrm{ppm}$ on the 13th day with the percentage of reduction about $88 \%$. Followed by GMP 4 isolate with $10 \mathrm{ppm}$ concentration to $2.02 \mathrm{ppm}$ with the percentage of reduction about $79 \%$. GMV 3 showed the lowest reduction isolate with concentration from 10 to 4.86 ppm on the 13th day with the percentage of reduction about $51.40 \%$, but still above $50 \%$. 
Table 1. The Potentially Methane Gas Reduction with 7 Isolates from rice Field in Gowa

\begin{tabular}{llllll}
\hline $\begin{array}{l}\text { Isolat } \\
\text { Code }\end{array}$ & \multicolumn{3}{l}{$\begin{array}{l}\text { Methane gas reduction (ppm) } \\
\text { in day } 1 \text { to....day }\end{array}$ 13th } & $\begin{array}{l}\text { Percentage of } \\
\text { Reduction(\%) }\end{array}$ \\
\hline & 1 & 3 & 9 & 13 & \\
\hline GMV 1 & 10 & 6.81 & 3.00 & 2.91 & 70,90 \\
GMV 3 & 10 & 8,09 & 5.00 & 4.86 & 51,40 \\
GMV 9 & 10 & 7.81 & 4.38 & 3.84 & 61,60 \\
GMR 1 & 10 & 3.46 & 2.56 & 2.56 & 74,40 \\
GMR 8 & 10 & 3.22 & 1.76 & 2.53 & 74,70 \\
GMP 2 & 10 & 2.48 & 1.61 & 1.20 & 88,00 \\
GMP 4 & 10 & 2.83 & 1.63 & 2.02 & 79,80 \\
\hline
\end{tabular}

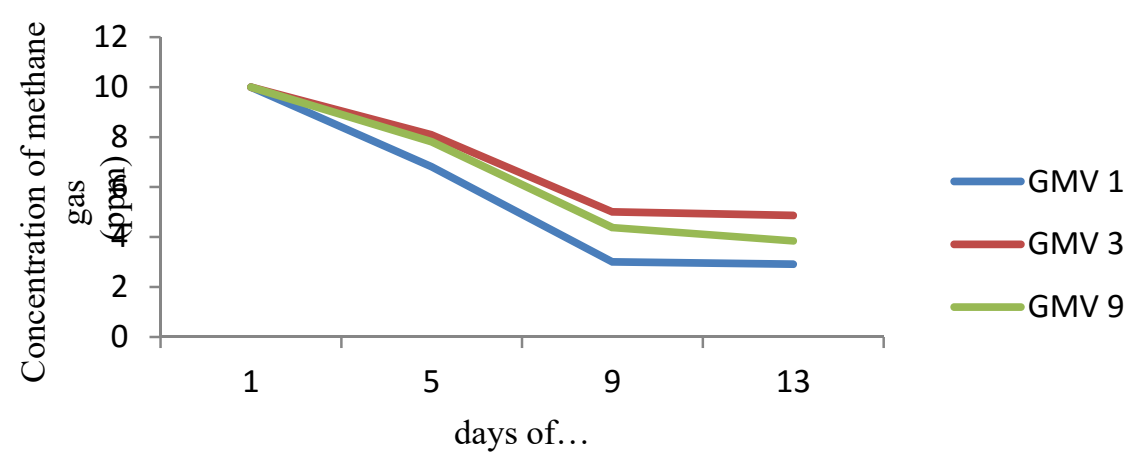

Figure 1. The reduction curve for GMV isolates

The reduction curve of GMV 1, GMV 3 and GMV 9 was presented in Figure 1. It shows that methane concentration of GMV 1, GMV 3 and GMV 9 decreased significantly after the observation on the 1st day until the 9th day. After that GMV 9 decreased slowly until on the 13th day. GMV 1 and GMV 3 more constan on the 13th day.

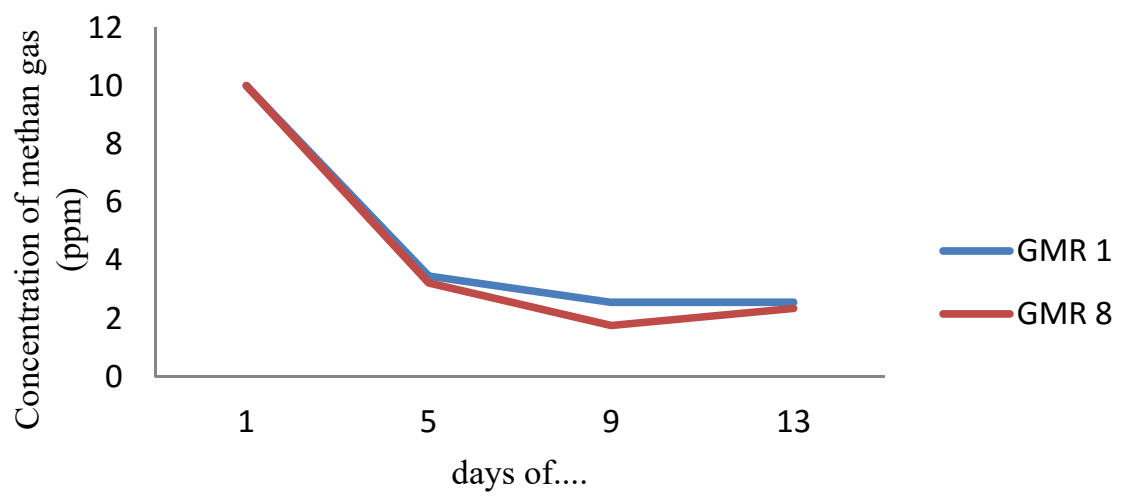

Figure 2.The reduction curve for GMR isolates

The reduction curve of GMR 1 and GMR 8 ( figure 2) shows that the concentration of methane decreased very sharply ( $3.46 \mathrm{ppm}$ and $3.22 \mathrm{ppm}$ ) on the 5th day then decreased gradually until the 9th day. For GMR 1, it was constant about $2.56 \mathrm{ppm}$ until 13th day, while GMR 8 increased to $2.53 \mathrm{ppm}$ on the 13th day. 


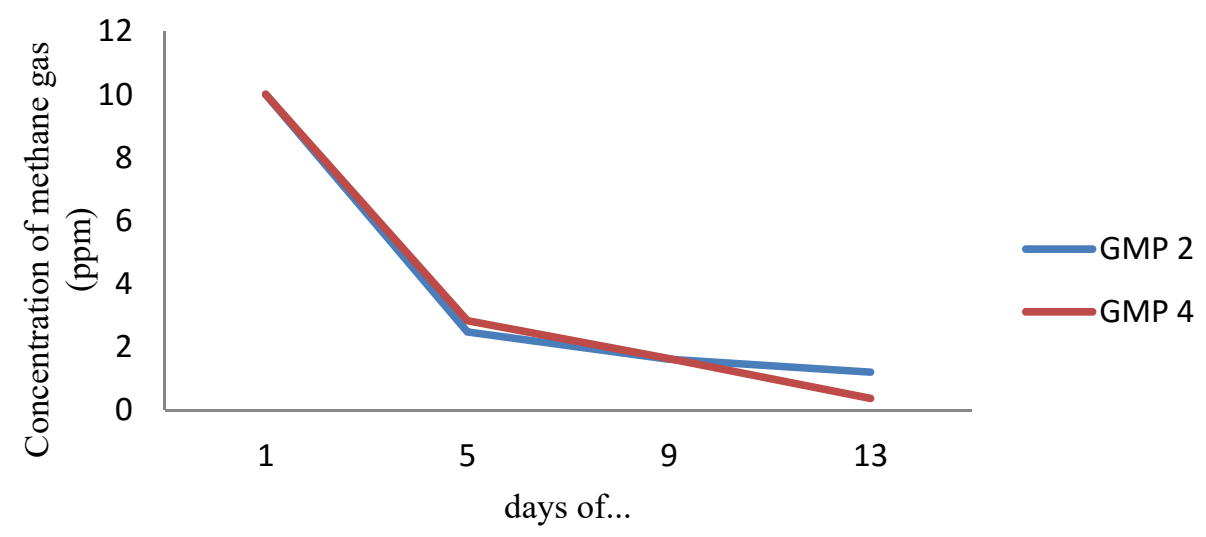

Figure 3.The teduction curve for GMP isolates

The reduction curve of GMP 2 and GMP 4 (figure 3) shows that the concentration decreased very sharply to $2.48 \mathrm{ppm}$ and $2.83 \mathrm{ppm}$ after the 1st day until the 5th day, decreased slowly to $1.61 \mathrm{ppm}$ and $1.63 \mathrm{ppm}$ on the 9th day. GMP 2 down to $1.20 \mathrm{ppm}$, whereas GMP 4 down slightly to $2.02 \mathrm{ppm}$ on the 13 th day.

\section{Discussion}

Metanotrophs bacteria have methane monooxygenase (MMO) as specific enzymes. According to Hanson and Hanson (1996) all methanotrophs bacteria can express MMO. Metanotrophs bacteria oxidizes methane in aerobic conditions with using specific enzyme systems, called methane monooxygenase (Madigan et al. 2000). Methane oxidation process can take place... with the enzymes. Methane is oxidized to methanol with the breaking dioxide from the MMO enzyme activities. The differences of the potentially reducing from each isolates may be caused bythe differences of enzyme activities .

The reduction of methane gas was generally very sharp shown from each isolate on the first day until the fifth day. After that it decreased slowly on the 13th day. The reduction related to the time and growth phase for the isolates. Each bacteria has a different growth for time, that required fast time e.g. 20 minutes, hours and even for days. Methanotrophs bacteria are type of bacteria that grow slowly (Begonja and Hrsak, 1998). Even on the specific medium NMS, the colonies are optimal to grow up at the age of 14 days.

The bacteria growth in the medium pass several phases i.e., lag, exponential, stationary and death phase. Lag phase is the adaption of the bacteria to their environment and begin to grow up slowly. Exponential phase is the breeding of bacteria to take place most rapidly. The stationary phase is the breeding of the bacteria with the same number with death. Autolysis phase is a death phases many for bacteria. Exponential phase is the increasing of volume and size for cells, as the result the population grews was supported with the opinion from Atlas et al in Nurhamida (2009) that after the adaptation phase completed, the microorganism enters to the exponential and stationary phases which the maximum rate is growing constant, so that number of maximum biomass contained in this phase. Based on research has been done by Nonci (2015), the 7th isolates had an average for the highest population on the 3th day until 5th, closing is an exponential and stationary phase, so it is possible to reduce methane massively.

The reductions for all isolates were starting slowly after 5th day. Even GMR 1 shows constant rate on the 9th day until the 13th day. The phenomenon was caused by the growth of bacteria entering the stationary phase to the autolysis phase, it can also be caused of the changes of physical conditions in the micro environment. This is with opinion from Pelczar and Chan (1986) that the growth process relies on the chemical reaction therefore the rate of reactions are influenced by temperature. In addition, there is also occurs nutrient competition so the reduction potential began to decrease. Some of the main factors that influence the growth of microorganisms involve the supply of nutrients, time, temperature, water, $\mathrm{pH}$ and oxygen availability (Buckle, 1985).

\section{Conclusion}

Based on the results that have been obtained, all isolates can be recommended as biological agent to reduce methane emissions, because it has potential to reduce methane gas over $50 \%$. The highest potential was shown by GMP 2 with concentration from 10 to $1.2 \mathrm{ppm}$ on the 13th day with the percentage of reduction about $88 \%$. The lowest shown by GMV 3 with concentration from 10 to $4.86 \mathrm{ppm}$ on 13 th day with percentage of 
reduction about was $51.40 \%$.

\section{References}

Anonymous. (2010). Panduan Inventori Gas Rumah Kaca dan Mitigasi Perubahan Iklim Sektor Pertanian. Departemen Pertanian (In Indonesia).

Begonja A, Hrsak D. (1998). Growth characteristic and metabolic activities of the methanotrophic-heterotrophic growndwater community. J.ppl Microbial, 85, 448-456.

Buckle, K. A. (1985). Ilmu Pangan, Penerbit Universitas Indonesia. Jakarta (In Indonesia)

Conrad, R., \& Rothfus, F. (1991). Methane Oxidation in the Soil Surface Layer of a Flooded Rice Field and the Effect of Ammonium. Biol Fertil Soil, 12, 28-32

Hanson, R., \& Hanson, T. E. (1996). Methanotropic Bacteria. J Microbiol Reviews, 60: 439-471

Hutchens, E., Radajewski, S., Dumont, M., McDonal, I., Colin, M. J. (2014). Analysis of methanotrophic bacteria in Movile Cave by stable isotope probing. Environmental Microbiology, 6, 111-120

Kumaraswarny,S., Ramakrishnan, B., Sethunathan, N. (2001). Methane production and oxidation in an anoxic redox species. J. Rnvion Quality, 30, 2195-2201.

Las, I. ( 2007). Menyiasati Fenomena Anomali Iklim bagi Pemantapan Produksi Padi Nasional pada Era Revolusi Hijau Lestari. Jurnal Biotek-LIPI. Naskah Orasi Pengukuhan Profesor Riset Badan Litbang Pertanian, Bogor, 6 Agustus 2004 (In Indonesia)

Madigan, M. T., Martinko, J. M., Parker, J. (2000). Brock Biology of Microorganisms. Edke-9. New Jersey: Prentice Hall.

Nonci, M., Baharuddin., Burhanuddin R., Pirman. (2015). Analysis of Population and Growth Rate Metanotrof Bacteria as Reducers Methane Gases Emission in Rice Field. International Journal of Science and Research (IJSR). Vol 4. Issue 9

Nurhamida. (2009). Optimasi Produksi Inokulan Pseudomonas sp dan Viabilitasnya dalam bahan Pembawa Gambut. Fakultas Matematika dan Ilmu Pengetahuan Alam Bogor (In Indonesia)

Pelczar, M. J., Chan, E.C.S. (2007). Elements of Microbiology. Mc Graw Hill Book Company. New York.

Peng, S., Huang, J., Sheelhy, J.E., Laza, R.C.,Visperas,R.M., Zhong,X., Centeno,G.S., Khush,G.S., Cassman,K.G. (2008). Rice yields decline with higher night temperature from global warming. Proc. Natl. Acad. Sci. USA 2004, 101,9971-9975.

\section{Copyrights}

Copyright for this article is retained by the author(s), with first publication rights granted to the journal.

This is an open-access article distributed under the terms and conditions of the Creative Commons Attribution license (http://creativecommons.org/licenses/by/3.0/). 